\title{
ArcheoSciences
}

Revue d'archéométrie

\section{Chupicuaro archaeological sites: from magnetic survey to excavation (late pre-classic period, Middle Lerma Valley, Guanajuato, Mexico)}

Vincent Bichet, Christophe Durlet, Christophe Petit, Véronique Darras and Brigitte Faugère

\section{(2) OpenEdition}

\section{Journals}

Electronic version

URL: https://journals.openedition.org/archeosciences/1229

DOI: 10.4000/archeosciences. 1229

ISBN: 978-2-7535-1599-4

ISSN: 2104-3728

Publisher

Presses universitaires de Rennes

\section{Printed version}

Date of publication: 30 October 2009

Number of pages: $31-33$

ISBN: 978-2-7535-0943-6

ISSN: $1960-1360$

\section{Electronic reference}

Vincent Bichet, Christophe Durlet, Christophe Petit, Véronique Darras and Brigitte Faugère,

"Chupicuaro archaeological sites: from magnetic survey to excavation (late pre-classic period, Middle Lerma Valley, Guanajuato, Mexico)", ArcheoSciences [Online], 33 (suppl.) | 2009, Online since 30

October 2011, connection on 01 February 2022. URL: http://journals.openedition.org/archeosciences/ 1229 ; DOI: https://doi.org/10.4000/archeosciences.1229 


\title{
Chupicuaro archaeological sites: from magnetic survey to excavation (late pre-classic period, Middle Lerma Valley, Guanajuato, Mexico)
}

\author{
Vincent Bichet*, Christophe Durlet**, Christophe Petit ${ }^{* * *}$, \\ Véronique DARras ${ }^{* * * *}$ and Brigitte FAUGÈrE ${ }^{* * * *}$
}

Key words: Magnetic survey, Vertical gradiometer, Pre-classic period, Chupicuaro, Mexico.

\section{AIMS OF THE PROJECT}

The area of Chupicuaro, located in the middle valley of the Lerma river, is regarded as one of the major archaeological targets of central Mexico for the late pre-classic period (600 BC-AD 300). Archaeological investigations in the area have been limited because of a large reservoir constructed in 1948 and severe plundering. Since 1999 a FrenchMexican research program has concentrated on broadening knowledge of the local Chupicuaro culture and its development (Faugère \& Darras, 2008).

A systematic pedestrian survey has collected archaeological artifacts revealed by erosion or illicit digging. More than one hundred sites have been located near the river and near carbonated hydrothermal springs around which most of the settlements seem to have clustered for several centuries. Because of the large number of sites and the absence of visible archaeological structures, a magnetic survey was carried out between 2002 and 2005 in nine sectors covering a total surface area of 7.6 hectares.

\section{SURVEY METHODS}

A GEOMETRICS G-858 Magmapper magnetometer integrated with a vertical gradiometer was used to remove variations of the terrestrial magnetic field. Its sensitivity is up to $0.025 \mathrm{nT} / \mathrm{m}$ and measurement frequency $0.2 \mathrm{~s}$. A $50 \mathrm{~m}$ square grid with one-meter spacing of measuring lines was used in the prospected areas. The density of point measurements is generally 3 to 5 per $\mathrm{m}^{2}$.

Two of the nine prospected sites revealed decametric circular, linear and/or quadrangular anomalies significant of archaeological structures. For one of them, site TR6 (Tarandacuao district), the magnetic survey $\left(10,420 \mathrm{~m}^{2}-\right.$ 38,465 points of measurement) resulted in field excavation

* University of Franche-Comté, UMR 6249 Chrono-Environnement, 16 route de Gray F-25030 Besançon. (vincent.bichet@univ-fcomte.fr)

** University of Burgundy, UMR CNRS 5561 Biogeosciences, 6 boulevard Gabriel, F-21000 Dijon.

*** University of Burgundy, UMR CNRS 5594 Arthéis, 6 boulevard Gabriel, F-21000 Dijon.

**** Maison de l'Archéologie et de l'Ethnologie, UMR CNRS 8096, 21 allée de l'Université, F-92023 Nanterre. 
(Fig. 1) which has created an opportunity for comparing the magnetic and archaeological maps.
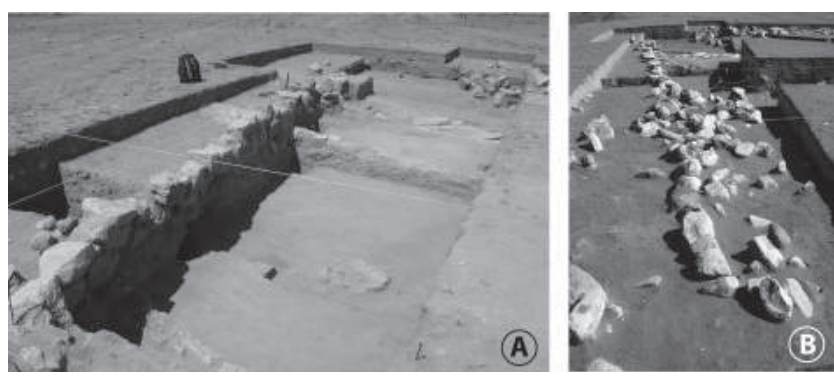

Figure 1: Views of the west wall of the quadrangular worship platform-unit A. (A) Standing north-western part; collapsed southwestern part (B).

\section{Main RESUlts}

The prospected area shows strong gradient anomalies $( \pm 150$ to $200 \mathrm{nT} / \mathrm{m})$ indicating three main structures (Fig. 2):

- to the south, a $35 \mathrm{~m}$ diameter circular structure (unit A) with slightly eccentric nodule;

- to the northeast, a quadrangular anomaly, $20 \mathrm{~m}$ to the side, consisting of four broad and irregular segments (unit B), associated with a small eccentric nodule;

- linear structure almost $60 \mathrm{~m}$ long, NNW-SSE axis (unit C), associated with a shorter 15-m segment located $10 \mathrm{~m}$ to the east (unit C').

Some point anomalies with the same intensity also exist, but without drawing specific structures.

The magnetic map also shows many anomalies of weak gradient $( \pm 25 \mathrm{nT} / \mathrm{m})$, the distribution of which does not seem to display any particular organization.

On the basis of the magnetic survey, an extensive excavation of $460 \mathrm{~m}^{2}$ covering the three major anomalies was undertaken in 2004 and 2005. It confirmed the presence of circular, quadrangular and linear features (Fig. 3). Their sizes are nearly the same as those of the recognized magnetic anomalies.

The anomalies systematically correspond to regular basalt blocks used in wall construction, found tumbled in a matrix of archaeological layers made up of volcanogenic and sedimentary silts and clays.

The magnetic susceptibility measured with a Bartington MS2 magnetic susceptibility meter indicates an average value of 280 CGS for basalts (8 samples) and of 550 CGS for the silts ( 4 samples). Such a high contrast implies that only wall blocks, collapsed or not, can be recognized by

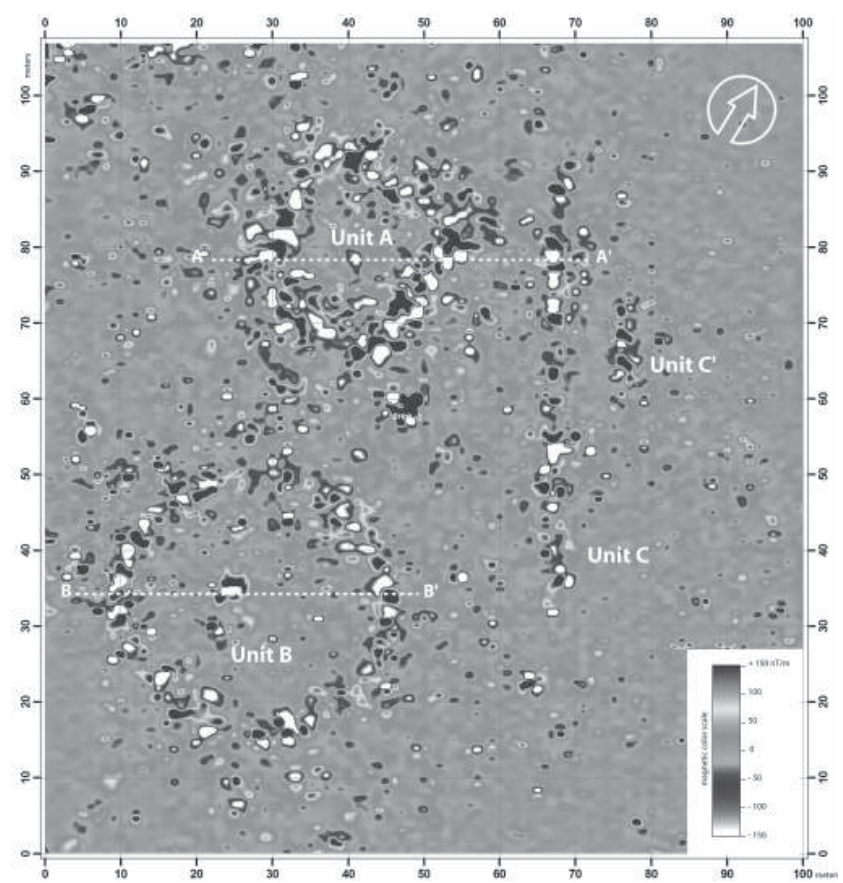

Figure 2 (see color plate): Magnetic vertical gradient map of the TR6 archaeological site.

magnetic survey (Fig. 1). To the contrary, constructions in adobe (Chupicuaro houses were built of silts and clays) are not detectable.

\section{ArChaeological Models}

Units A and B are interpreted as "patio hundidos", traditional worship platforms built of fill encased by stone walls and with a room arranged in the center (Beekman, 2008; Brambila \& Castañeda, 1993). The circular feature corresponds to the beginning of the late Chupicuaro cultural period (400-300 BC), while the quadrangular one is allotted to the final late Chupicuaro (200-100 BC). The eccentric nodule of unit A corresponds to two big isolated blocks near a late fireplace associated with a heap of stones (AD 100). Structure C (and probably C') corresponds to the external edge of a large platform built during the Mixtlan period (AD 100-250), probably the latest occupation of the settlement.

In this kind of context the magnetic survey proves to be an effective means for the detection of major archaeological structures. 
Figure 3 (see color plate):

Archaeological map of site TR6.

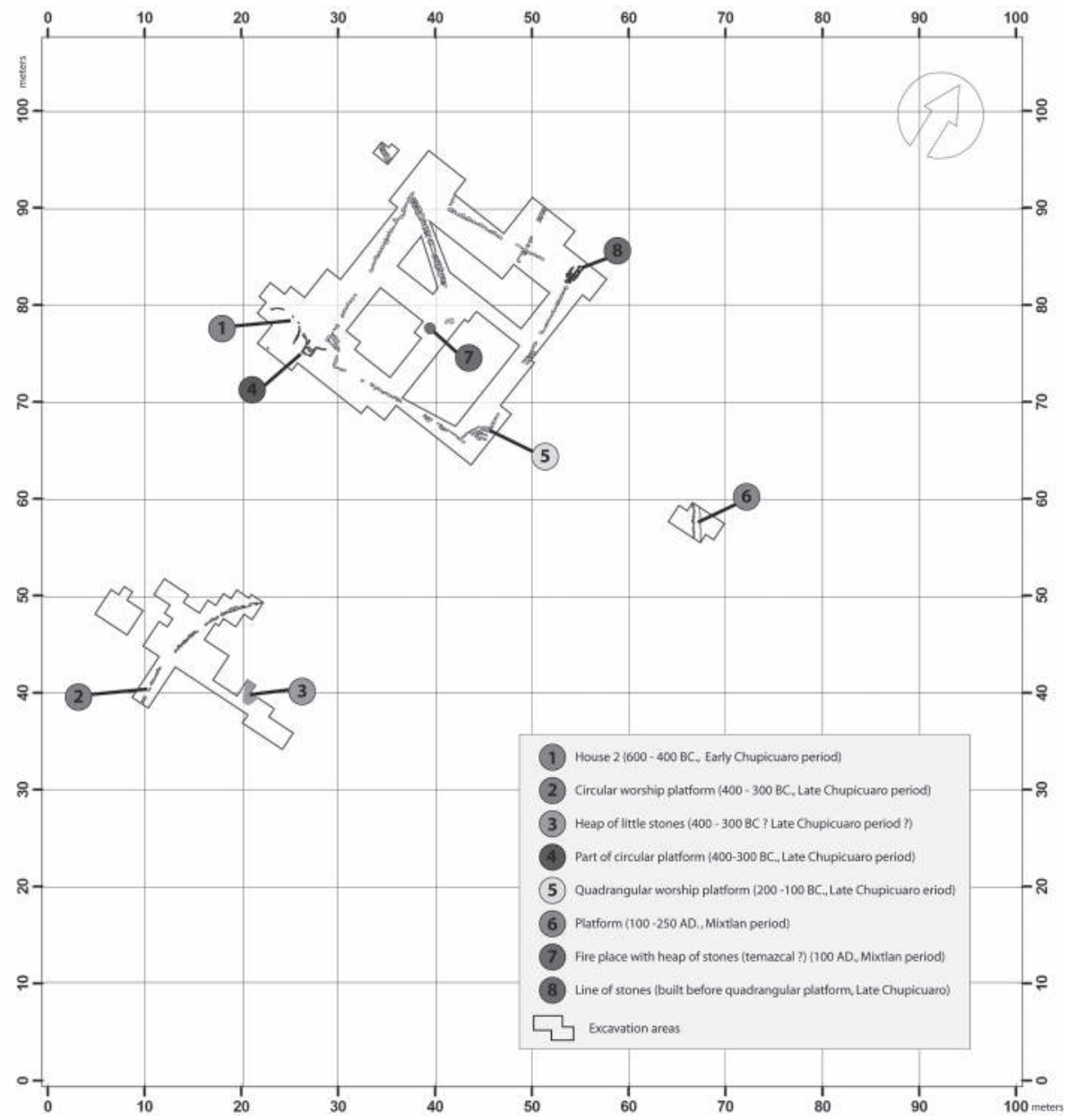

\section{References}

Faugère, B. and Darras, V., 2008. Gestión del espacio en Chupícuaro, Guanajuato. El patrón del asentamiento en el valle de Acámbaro durante la fase Chupícuaro reciente (400100 a.C.). Tiempo y región. Estudios históricos y sociales, Volumen II, Ana María Crespo, In Memoriam. Carlos Viramontes, coordinador INAH, Archivo Municipal de Querétaro, Universidad Autónoma de Querétaro, México, 177-213.
Beekman, C., 2008. Corporate Power Strategies in the Late Formative to Early Classic Tequila valleys of Central Jalisco. Latin American Antiquity 19 (4): 414-434.

Brambila, R. and Castañeda, C., 1993. Los basamentos con espacios hundidos. Cuadernos de arquitectura mesoamericana 25: 73-78. 